\title{
Directed self-assembly of monodisperse phospholipid bilayer Nanodiscs with controlled size.
}

\section{Supplementary Information}

\author{
Denisov, I.G. ${ }^{\text {a,c }}$, Grinkova, Y.V., ${ }^{\text {a,c }}$ Lazarides, A.A. ${ }^{\text {, }}$, Sligar, S.G ${ }^{\text {a,b,c,*}}$. \\ ${ }^{a}$ Departments of Biochemistry, ${ }^{b}$ Chemistry, and ${ }^{c}$ Beckman Institute, University of Illinois, \\ Urbana, Illinois 61801, and ${ }^{d}$ Department of Mechanical Engineering and Material \\ Science, Duke University, Durham, NC 27708 \\ * Corresponding Author.
}

Corresponding address:

Stephen G. Sligar

University of Illinois Urbana-Champaign

135 Morrill Hall

505 S. Goodwin Avenue

Urbana, IL 61801 s-sligar@uiuc.edu

Phone: (217) 244-9872

Fax: (217) 265-4073 


\section{MSP1 Sequence}

Amino acid sequence of MSP1(1-200) as referred in the text and Table 1:

LKLLDNWDSVTSTFSKLREQLGPVTQEFWDNLEKETEGLRQEMSKDLEEVKAK VQPYLDDFQKKWQEEMELYRQKVEPLRAELQEGARQKLHELQEKLSPLGEEMR DRARAHVDALRTHLAPYSDELRQRLAARLEALKENGGARLAEYHAKATEHLST LSEKAKPALEDLRQGLLPVLESFKVSFLSALEEYTKKLNTQ

\section{Expression and purification of TEV protease.}

E. coli strain BL21(DE3)-RIL/pRK793 which produces autoinactivation resistant mutant of TEV protease was purchased from Science Reagents, Inc. (El Cajon, CA). Expression and purification of the protein was carried out as described elsewhere ${ }^{1}$ with some modifications. Briefly, the cells were grown on 2 XYT medium supplemented with $100 \mathrm{mg} / \mathrm{l}$ ampicillin and $30 \mathrm{mg} / \mathrm{l}$ chloroamphenicol at $37{ }^{\circ} \mathrm{C}$ to mid-log phase $\left(\mathrm{A}_{600}=0.8\right.$ 1.0) and induced with IPTG (final concentration $1 \mathrm{mM}$ ). The culture was grown for additional 4 hours at $30{ }^{\circ} \mathrm{C}$. The cells were harvested by centrifugation and stored at $80^{\circ} \mathrm{C}$. For purification the cells collected from five liters of culture were resuspended in $100 \mathrm{ml}$ of lysis buffer $(50 \mathrm{mM}$ Tris/ $\mathrm{HCl}, 10 \mathrm{mM} \beta$-mercaptoethanol (BME), $0.1 \%$ Triton $\mathrm{X}-100,5 \%$ glycerol, $\mathrm{pH} 8.0$ ), lysed by sonication and centrifuged at 30,000 g for $30 \mathrm{~min}$. The supernatant was loaded onto $2.5 \times 6 \mathrm{~cm}$ column packed with metal-chelating resin (Amersham Biosciences, Piskataway, $\mathrm{NJ}$ ), charged with $\mathrm{Ni}^{2+}$ and equilibrated with lysis buffer. The column was washed with 10 bed volume of washing buffer (lysis buffer, containing $50 \mathrm{mM}$ imidazole and $0.3 \mathrm{M} \mathrm{NaCl}$ ), and the protein was eluted with the same buffer containing $0.5 \mathrm{M}$ of imidazole. The buffer was exchanged to $2 \mathrm{x}$ storage buffer (100 mM Tris/HCl, 2 mM EDTA, $10 \mathrm{mM}$ DTT, 0.2\% Triton X-100, pH 7.5) by dialysis or on desalting column filled with Sephadex G-25 (Sigma, St. Louis, MO). Protein concentration was estimated with Coomassie reagent (Pierce Biotechnology, Rockford, IL) using bovine serum albumin as a standard, then the sample was mixed with equal volume of glycerol, aliquoted and stored at $-80^{\circ} \mathrm{C}$.

(1)Kapust, R.B.; Tozser, J.; Copeland, T.D.; Waugh, D.S., BBRC 2002, 294, 949-955. 


\section{Affinity tag cleavage with TEV-protease.}

About $50 \mathrm{mg}$ of MSP at the concentration $0.5-5 \mathrm{mg} / \mathrm{ml}$ in $20 \mathrm{mM}$ Tris/ $\mathrm{HCl}$ buffer $\mathrm{pH} 7.5$ containing $0.1 \mathrm{M} \mathrm{NaCl}, 1 \mathrm{mM}$ EDTA, and $1 \mathrm{mM}$ DTT was mixed with $1 \mathrm{mg}$ of TEV protease and incubated overnight at ambient temperature. Next day the buffer in the reaction mixture was exchanged to $50 \mathrm{mM}$ Tris/ $\mathrm{HCl} \mathrm{pH} 8.0$ containing $0.3 \mathrm{M} \mathrm{NaCl}$ and $50 \mathrm{mM}$ imidazole, and the sample was loaded onto 1X5 $\mathrm{cm}$ column packed with metalchelating resin charged with $\mathrm{Ni}^{2+}$. The column was washed with 2 bed volumes of the loading buffer (in case of MSP1TEV the buffer contained $50 \mathrm{mM}$ cholate in addition to the components listed above), the flow-through was combined, concentrated, analyzed on SDS-PAGE, and dialyzed against the disc reconstitution buffer.

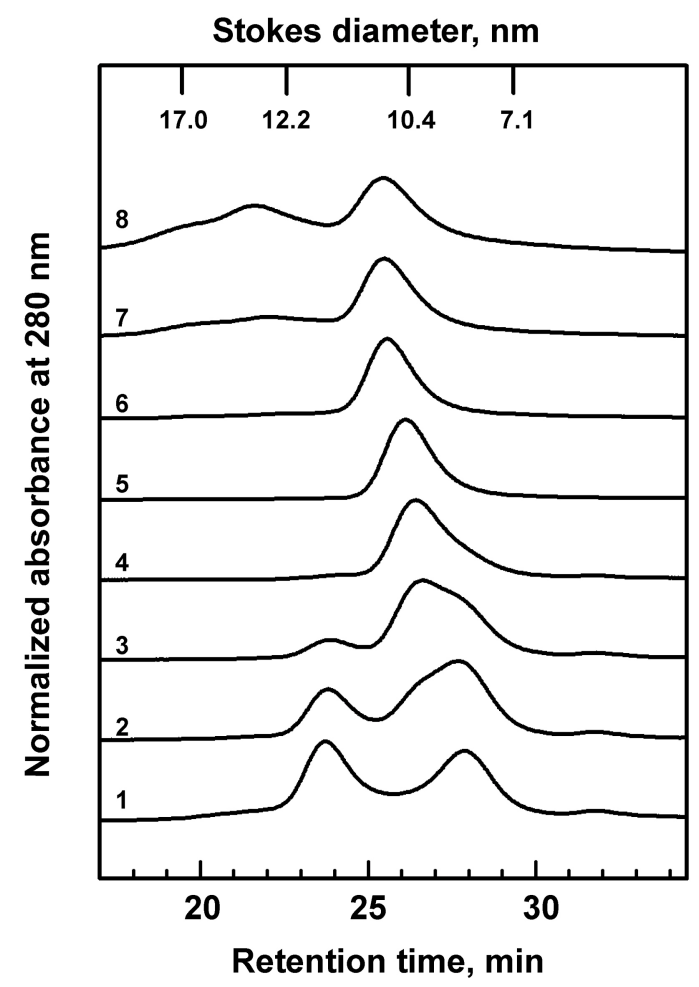

Figure S1. HPLC separation curves for different lipid/protein ratio in self-assembly mixture with MSP1E1 (Table 1, entry 2). Molar lipid/protein ratio for both panels: $1-0$, $2-25,3-50,4-75,5-100,6-150,7-200,8-300$. 


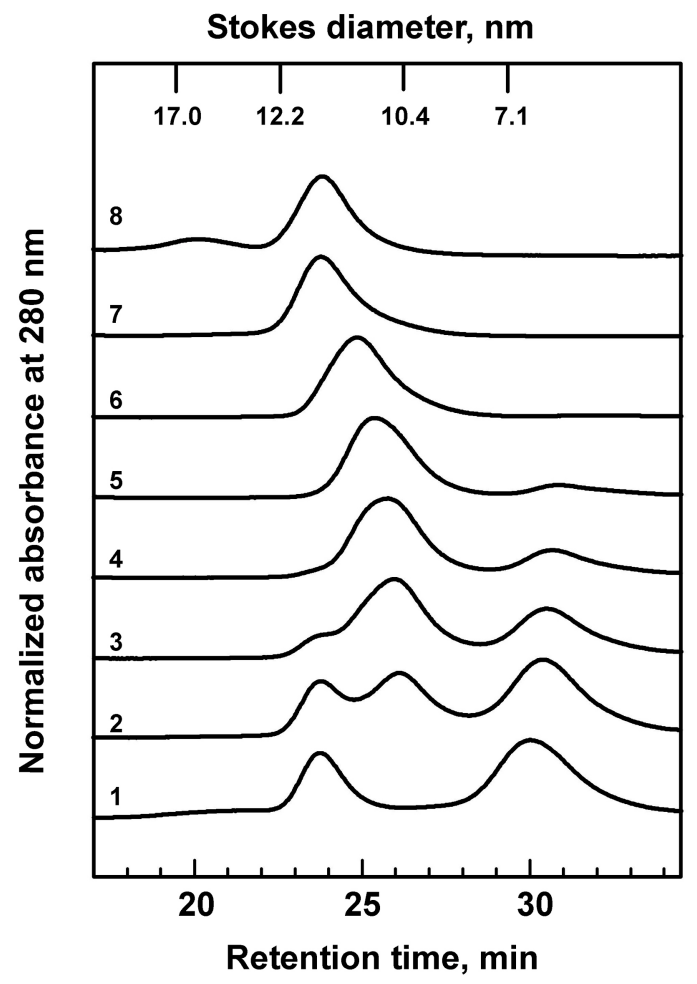

Figure S2. HPLC separation curves for different lipid/protein ratio in self-assembly mixture with MSP1E3 (Table 1, entry 4). Molar lipid/protein ratio for both panels: $1-0$, $2-25,3-50,4-75,5-100,6-150,7-200,8-300$. 


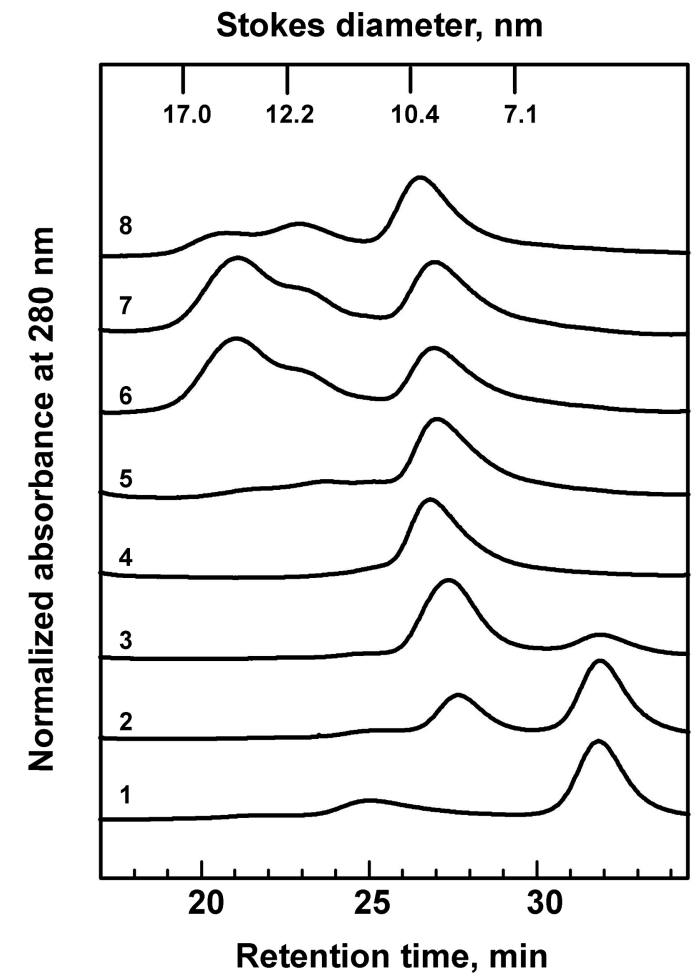

Figure S3. HPLC separation curves for different lipid/protein ratio in self-assembly mixture with MSP1D1 (Table 1, entry 7). Molar lipid/protein ratio for both panels: 1 - 0 , $2-25,3-50,4-75,5-100,6-150,7-200,8-300$. The data obtained with MSP1D1(-) (Table 1, entry 8) look very similar (not shown). 


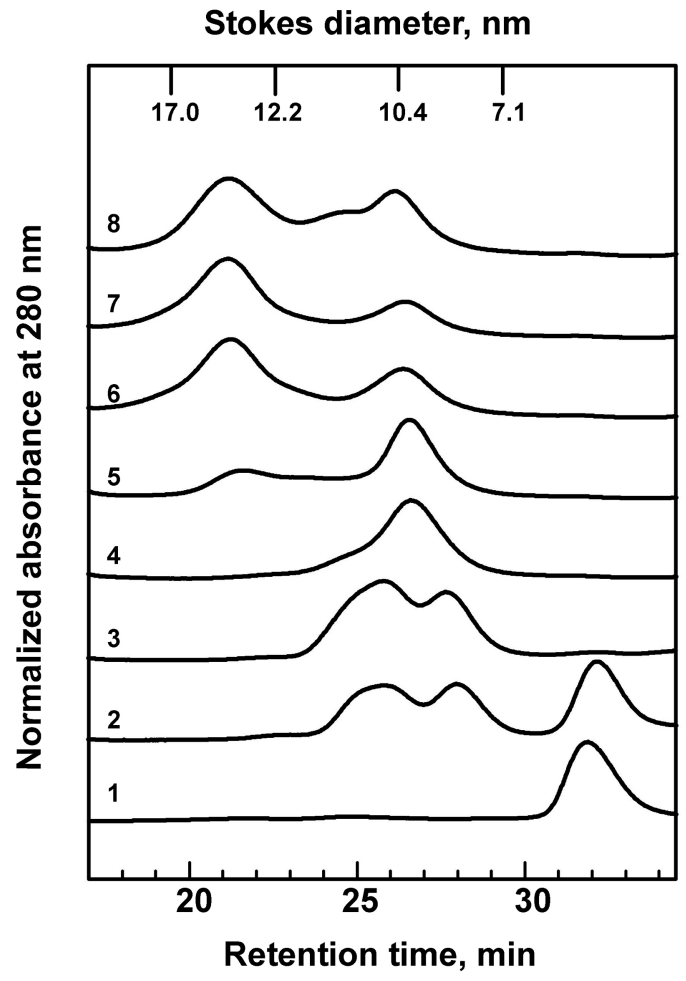

Figure S4. HPLC separation curves for different lipid/protein ratio in self-assembly mixture with MSP1D2-P23S (Table 1, entry 10). Molar lipid/protein ratio for both panels: $1-0,2-25,3-50,4-75,5-100,6-150,7-200,8-300$. The data obtained with MSP1D2 (Table 1, entry 9) and with MSP1D2-P23S(-)(Table 1, entry 11) are very similar (not shown). 